\title{
ON-SITE UPGRADING : STRATEGI MEMENUHI ADEQUATE HOUSING DI KAMPUNG KOTA
}

(On-Site Upgrading : Strategies to Fullfill the Needs of Adequate Housing in Kampung Kota)

\author{
Sekar Ari Utari ; Dr. Ir. Dwita Hadi Rahmi, M.A ; Ir. Ikaputra, M.Eng., Ph.D \\ Universitas Gadjah Mada \\ JI. Grafika No. 2 Kampus UGM, Yogyakarta 55281 \\ arisekar@rocketmail.com
}

\begin{abstract}
Housing and settlement conditions are still things that need to be resolved in Indonesia. Settlements in many cities in Indonesia still have many shortcomings in terms of physical conditions and basic infrastructure. The government has tried a method to overcome this problem through the Kampung Improvement Program (KIP). However, KIP has not been able to solve the problem whose effects are sustainable. There are still many urban poor living in slums urban areas. Given the above understanding, there is an urgency to look into a method to solve the problems. On-site upgrading is a step that can be used as a method for solving Kampung problems in Indonesia. This paper examines what and how the concept of on-site upgrading can provide sustainable effects in Indonesia.
\end{abstract}

Keywords: on-site upgrading, adequate housing, kampung kota

\begin{abstract}
Abstrak
Kondisi perumahan dan permukiman masih menjadi permasalahan yang perlu diperhatikan di Indonesia. Permukiman di banyak kota di Indonesia masih memiliki banyak kekurangan dalam hal kondisi fisik dan infrastruktur dasar. Pemerintah telah mencoba untuk mengatasi permasalahan tersebut melalui Kampung Improvement Program (KIP). Namun KIP ternyata belum cukup mampu untuk menyelesaikan permasalahan tersebut sebagai sebuah program yang efeknya berkelanjutan. Hal ini dapat dilihat dari masih banyaknya masyarakat miskin yang hidup di kampung kumuh perkotaan. Dengan pemahaman di atas, terdapat urgensi yang membutuhkan solusi terkait metode yang tepat dalam menyelesaikan permasalahan kampung di perkotaan. On-site upgrading merupakan salah satu langkah yang dapat digunakan sebagai metode penyelesaian permasalahan kampung kota di Indonesia. Tulisan ini mengkaji mengenai konsep on-site upgrading seperti apa yang dapat memberikan efek berkelanjutan di Indonesia.
\end{abstract}

Kata kunci: on-site upgrading, adequate housing, kampung kota

\section{Pendahuluan}

Kondisi perumahan dan permukiman masih menjadi permasalahan yang perlu di perhatikan di Indonesia. Permukiman di banyak kota di Indonesia masih memiliki banyak kekurangan dalam hal kondisi fisik dan infrastruktur dasar. Pemerintah telah mencoba untuk mengatasi permasalahan tersebut melalui Kampung Improvement
Program (KIP). Namun KIP ternyata belum cukup mampu untuk menyelesaikan permasalahan tersebut sebagai sebuah program yang efeknya berkelanjutan. Hal ini dapat dilihat dari masih banyaknya masyarakat miskin kota yang masih tinggal di kampung kumuh perkotaan. 
Dengan pemahaman di atas, terdapat urgensi yang membutuhkan solusi terkait metode yang tepat dalam menyelesaikan permasalahan kampung di perkotaan.

\section{Metode}

\section{Studi Literatur}

Dalam melakukan penelitian setiap peneliti memerlukan metode untuk dapat menyusun penelitian secara baik dan tepat sehingga tujuan penelitian dapat di capai. Pada kesempatan kali ini tim penulis melakukan penelitian dengan menggunakan metode literature review atau yang sering pula disebut dengan studi literatur. Studi literatur mengkompilasi dan mengevaluasi penelitian yang tersedia pada topic atau isu tertentu. Proses penulisan Studi Literatur dilakukan dengan langkah berikut ini :

\section{Menentukan topik yang akan dibahas}

2. Melakukan riset terhadap literaturliteratur yang relevan. Penulis membaca dan mencatat poin inti, kesimpulan, kekuatan dan kelemahan dari sebuah statement penelitian dalam bentuk kutipan.

3. Melakukan Analisis dan Evaluasi melalui tahapan peniliaian bagaimana sebuah sumber literasi berkaitan dengan sumber literasi yang lain dalam konteks topik yang diangkat oleh penulis. Penulis melakukan pengelompokan dalam sub tema yang dituliskan dalam sub-sub judul tulisan. Penulis juga melakukan telaah dan kritik evaluasi terhadap penelitian tersebut.

4. Menuliskan pernyataan-pernyataan tesis atas hasil telaah dan kritik evaluasi dari kelompok sub-sub judul.

5. Menuliskan studi literatur tersebut ke dalam satu kesatuan tulisan yang utuh dengan menyertakan rigkasan, analisis, sintesis serta evaluasi. Ringkasan menyatakan secara singkat argument dan poin utama yang relevan terhadap penelitian. Analisis dilakukan dengan memahami pernyataan penelitian dan menginterpretasikan dengan kacamata topik yang telah ditentukan. Evaluasi dilakukan dengan menilai pernyataan penelitian berdasarkan kriteria yang telah dipilih oleh penulis. Sintesis dilakukan dengan menggabungkan ide untuk membentuk pernyataan tesis baru melalui narasi kritis dan perbandingan.

\section{Kajian Teori}

\section{Urban Settlements}

Urban Settlement merupakan frase yang terdiri dari dua kata yaitu Urban dan Settlements. Apabila dipahami lebih dalam Urban menurut Nagle dapat didefinisikan sebagai wilayah yang memiliki karakteristik spesifik seperti populasi yang besar, populasi tersebut berpersentase tinggi bekerja di bidang manufaktur dan jasa, dan area besar yang dibangunpun memiliki fungsi administratif tertentu. Sementara definisi Settlements menurut Nagle adalah tempat di mana orang tinggal dan di mana mereka dapat terlibat dalam berbagai kegiatan, seperti perdagangan, pertanian, atau manufaktur.

Urban having specific characteristics such as a large population, with a high percentage employed in manufacturing and services; a large built up area with specific administrative functions (Nagle, 1998)

A Settlement can be defined as a place in which people live and where they may be involved in various activities, such as trade, agriculture, or manufacturing (Nagle, 1998)

Singh menyatakan settlements atau yang dalam bahasa Indonesia sering disebut dengan permukiman dapat diklasifikasikan menjadi dua tipe urban dan rural. Perkotaan ("urb" latin berarti kota atau kota) mencakup pemukiman di mana sebagian besar penduduk yang bekerja terlibat dalam pekerjaan non-pertanian sementara pedesaan (latin "rus" yang berarti negara) berbeda dengan kota, menunjukkan pengelompokan fitur 
pemukiman yang lebih sederhana dimana sebagian besar penduduk yang bekerja terlibat dalam eksploitasi sumber daya intrinsik tanah.

Settlements are usually classified into two types urban and rural. Urban (latin "urbs" meaning town or city) includes any settlement in which most of the working inhabitants are engaged in non-agricultural occupations while rural (latin "rus" meaning country) in contrast to the town, denotes a rather simple grouping of settlement features in which most of the working population engaged in the exploitation of the intrinsic resources of the land. (Singh, 1995)

Clark dalam (Singh, 1995) menyatakan Istilah pemukiman perkotaan diterapkan pada agregat yang relatif besar dari tempat tinggal dan daerah padat yang dibangun terhubung dengan ruang terbuka, mayoritas penduduk permukiman perkotaan secara ekonomi terlibat dalam kegiatan yang berkaitan dengan sektor sekunder, tersier dan kuaterner. Pemukiman perdesaan biasanya berukuran kecil dan jumlah populasi manusia yang jauh lebih sedikit dan tingkat serta kerumitan humanisasi yang lebih rendah. Pemukiman perkotaan mewakili bentuk tertinggi humanisasi dalam jumlah dan kompleksitas.

"The term urban settlement is loosely applied to a relatively large aggregate of dwellings and densely built-up area with its associated open spaces where the majority of the economically occupied inhabitants are engaged in activities mainly concerned with secondary, tertiary and quaternary sectors." Clark dalam (Singh, 1995)

"Rural settlements are usually small in size and much less compact aggregates of human population and the extent and complexity of humanization is the lowest in these rural settlement. Urban settlements represent the highest forms of humanization in both amount and complexity." Clark dalam (Singh, 1995)

Indonesia memiliki fenomena yang unik terkait dengan urban settlements. Kawasan permukiman di perkotaan seringkali disebut dengan istilah kampung padahal kampung merupakan istilah permukiman kawasan pedesaan.

\section{Kampung Kota sebagai fenomena Urban Settlement di Indonesia}

Newberry dalam (Sumintarsih \& Adrianto, 2014) menyebutkan kampung dari segi tata ruang didefinisikan sebagai wilayah tempat tinggal. Kampung dipihak lain adalah bagian dari struktur administrasi yang mencakup wilayah perkotaan dan pedesaan yang terentang dari kelompok kelompok kecil perumahan hingga tingkat provinsi.

Wiryomartono dalam (Simarmata, 2018) menyampaikan gagasan istilah "kampung kota" atau "urban kampung" sebagai frase yang menggambarkan permukiman yang berkembang di daerah perkotaan tanpa (dasar) perencanaan infrastruktur atau jaringan ekonomi perkotaan.

...the notion of "kampung kota" or "urban kampung" describe "a settlement developed in an urban area without (basic) infrastructure planning or urban economic network Wiryomartono dalam (Simarmata, 2018).

Dari kedua definisi tersebut dapat disimpulkan, bahwa kampung kota adalah suatu wilayah permukiman di wilayah perkotaan yang berkembang tanpa dasar perencanaan infrastruktur atau jaringan ekonomi perkotaan.

Kampung kota tumbuh dan berkembang sebagai akibat dari meningkatnya aktivitas, peran dan ketergantungan akan kota bagi sebagian besar orang yang disebabkan oleh faktor ekonomi perkotaan. (Nugroho, 2010). Apabila melihat sejarah kampung perkotaan di Indonesia dapat ditelisik bahwa keberadaannya telah lama ada. (Raharjo, 2010) menyatakan bahwa kampung-kampung menunjukkan 
hubungan yang kuat dan sejarah urban yang dapat dilacak sejak masa prakolonial.

Kampungs show a strong
relationship and urban history that
can be traced since pre-colonial
times. (Raharjo, 2010)

Setiawan dalam (Sumintarsih \& Adrianto, 2014) menjelaskan bahwasannya istilah kampung kota atau disebut kampung digunakan sejak awal abad ke 20 oleh pemerintah Kolonial Belanda melalui program yang disebut kampung verbrecting. Sejak awal pemerintah Kolonial Belanda telah memisahkan secara tegas antara warga kampung (indlandsche Gemeente) dengan warga priyayi, pamong praja (stads Gemeente). Penggunaan istilah kampung kemudian juga dipakai oleh Indonesia dengan Program Perbaikan Kampung atau KIP yang dimulai sejak awal tahun 1960-an untuk mendefinisikan permukiman,

Funo dkk menyatakan salah satu fitur unik dari Indonesia adalah bahwa pemukiman perkotaan disebut juga sebagai kampung. Pemukiman manusia di daerah berkembang seperti Indonesia terus mempertahankan karakteristik pedesaan, konsep semacam itu berlaku untuk kelompok bermukim di perkotaan sehingga pemukiman perkotaan juga disebut kampung.

It is one unique feature of Indonesia that urban settlements are also called kampungs. It is often said that human settlements in developing regions continue to preserve the characteristics of rural village, and such a concept applies to kampungs.(Funo, Yamamoto, \& Silas, 2002)

Hutama dalam tesisnya berpendapat bahwa orang yang tinggal di kampung membawa identitas mereka dari desa perkotaan ke kampung. Akibatnya, pertumbuhan kampung sebagai lingkungan multidimensi dengan entitas fisik, sosial dan ekonomi. Kampung Perkotaan memiliki komunitas heterogen dari penghuni yang kompleks dengan nilai-nilai tradisional.

People who live in a kampung bring
their identity from an urban village to
the kampung. As a result, kampungs
growth as multi-dimensional
neighbourhoods with physical, social
and economic entities. Urban
Kampung have heterogeneous
communities of complex inhabitants
often with traditional values.
(Hutama, 2016)

\section{Karakteristik dan Permasalahan Kampung Kota}

Kampung kota adalah suatu bentuk permukiman di wilayah perkotaan dengan karakteristik antara lain perilaku penduduknya masih seperti dalam kehidupan pedesaan yang terjalin ikatan kekeluargaan yang erat, kondisi fisik bangunan dan lingkungan kurang baik dan tidak beraturan, kerapatan bangunan, penduduk padat, sarana prasarana serba kurang (Sumintarsih \& Adrianto, 2014). Dalam konteks pembangunan perkotaan (Funo et al., 2002) berpendapat kampung memiliki citra negatif yang merupakan pemukiman dengan kepadatan tinggi yang tidak memiliki infrastruktur dasar dan didominasi oleh kaum miskin kota.
in the context of urban development, kampungs have a negative image being high density settlements that lack basic infrastructure and are dominated by urban poor (Funo et al., 2002)

Catatan-catatan seperti kondisi fisik bangunan dan lingkungan yang kurang baik, ketidakteraturan, kerapatan bangunan serta sarana-prasarana yang kurang inilah yang memerlukan solusi. Seringkali kita mendengar istilah rumah yang layak bagi masyarakat kota, namun rumah seperti apakah sebenarnya yang dibutuhkan dan semestinya disediakan untuk masyarakat. Sebuah konsep terhadap rumah yang layak bagi masyarakat kota perlu disarikan sebagai dasar agar tujuan dari sebuah perbaikan dapat dicapai. 


\section{Hasil Penelitian dan Pembahasan}

\section{Adequate Housing}

Kementerian Perumahan Rakyat dalam ("Peraturan Menteri Negara Perumahan Rakyat Republik Indonesia No: 22 / PERMEN / M / 2008 tentang Standar Pelayanan Minimal Bidang Perumahan Rakyat Daerah Provinsi dan Daerah Kabupaten/Kota," 2008) menjelaskan bahwa rumah layak huni adalah rumah yang memenuhi persyaratan keselamatan bangunan dan kecukupan minimum luas bangunan serta kesehatan penghuninya.

.... the right to adequate housing should not be interpreted narrowly. Rather, it should be seen as the right to live somewhere in security, peace and dignity. (UNHC-HR, 2009)

\begin{abstract}
The right to adequate housing contains entitlements. These entitlements include: Security of tenure; Housing, land and property restitution; Equal and nondiscriminatory access to adequate housing; Participation in housingrelated decision-making at the national and community levels. (UNHC-HR, 2009)
\end{abstract}

Menurut pernyataan-pernyataan di atas maka Adequate Housing merupakan rumah yang memenuhi persyaratan keselamatan bangunan dan kecukupan minimum luas bangunan serta kesehatan penghuninya. Adequate Housing juga merupakan pemenuhan dari hak manusia terkait dengan hak untuk tinggal dengan aman, damai, dan bermartabat. Adequate housing mengandung maksud untuk memenuhi hak manusia terkait keamanan kepemilikan, perumahan, tanah, dan restitusi properti; akses yang setara dan tidak diskriminatif terhadap hunian, serta partisipasi terkait perumahan di tingkat nasional maupun komunitas.

\section{Kriteria Adequate Housing}

Sejumlah kondisi harus dipenuhi sebelum sebuah tempat dapat dianggap sebagai "perumahan yang layak." (UN-Habitat, 2015). Elemen-elemen ini sama mendasarnya dengan pengadaan dan ketersediaan perumahan. Perumahan yang memadai, minimal harus, memenuhi kriteria berikut (UN-Habitat, 2015):

1. Keamanan kepemilikan: perumahan tidak memadai jika penghuninya tidak memiliki jaminan kepemilikan yang menjamin perlindungan hukum terhadap penggusuran paksa, pelecehan dan ancaman lainnya.

2. Ketersediaan layanan, bahan, fasilitas dan infrastruktur: perumahan tidak memadai jika penghuninya tidak memiliki air minum yang aman, sanitasi yang memadai, energi untuk memasak, pemanasan, penerangan, penyimpanan makanan atau pembuangan sampah.

3. Keterjangkauan: perumahan tidak memadai jika biayanya mengancam atau membahayakan kenyamanan penghuni dari hak asasi manusia lainnya.

4. Kelayakan huni: perumahan tidak memadai jika tidak menjamin keamanan fisik atau menyediakan ruang yang cukup, serta perlindungan terhadap dingin, lembab, panas, hujan, angin, ancaman lain untuk kesehatan dan bahaya struktural.

5. Aksesibilitas: perumahan tidak memadai jika kebutuhan khusus kelompok yang kurang beruntung dan terpinggirkan tidak diperhitungkan.

6. Lokasi: perumahan tidak memadai jika terputus dari peluang kerja, layanan perawatan kesehatan, sekolah, pusat penitipan anak dan fasilitas sosial lainnya, atau jika berlokasi di daerah yang tercemar atau berbahaya.

7. Kecukupan budaya: perumahan tidak memadai jika tidak menghormati dan memperhitungkan ekspresi identitas budaya.

Secara spesifik Pemerintah Indonesia melalui Kementerian Perumahan Rakyat juga telah menjabarkan Kriteria teknis rumah layak huni dalam ("Peraturan Menteri Negara Perumahan Rakyat Republik Indonesia No : 22 / PERMEN / M / 2008 tentang Standar Pelayanan Minimal Bidang Perumahan Rakyat Daerah Provinsi dan Daerah Kabupaten/Kota," 
2008). Kriteria rumah layak huni tersebut meliputi :

1. Memenuhi persyaratan keselamatan bangunan

a. Ketentuan Struktur Bawah (Pondasi)

1) Pondasi harus ditempatkan pada tanah yang mantap, yaitu ditempatkan pada tanah keras, dasar pondasi diletakkan lebih dalam dari $45 \mathrm{~cm}$ dibawah permukaan tanah.

2) Seluruh badan pondasi harus tertanam dalam tanah

3) Pondasi harus dihubungkan dengan balok pondasi atau sloof, baik pada pondasi setempat maupun pondasi menerus

4) Balok pondasi harus diangkerkan pada pondasinya, dengan jarak angker setiap 1,50 meter dengan baja tulangan diameter $12 \mathrm{~mm}$

5) Pondasi tidak boleh diletakkan terlalu dekat dengan dinding tebing, untuk mencegah longsor, tebing diberi dinding penahan yang terbuat dari pasangan atau turap bambu maupun kayu

b. Ketentuan Struktur Tengah

1) Bangunan harus menggunakan kolom sebagai rangka pemikul,

2) dapat terbuat dari kayu, beton bertulang, atau bajaKolom harus diangker pada balok pondasi atau ikatannya diteruskan pada pondasinya

3) Pada bagian akhir atau setiap kolom harus diikat dan disatukan dengan balok keliling/ring balok dari kayu, beton bertulang atau baja

4) Rangka bangunan (kolom, ring balok, dan sloof) harus memiliki hubungan yang kuat dan kokoh

5) Kolom/tiang kayu harus dilengkapi dengan balok pengkaku untuk menahan gaya lateral gempa

6) Pada rumah panggung antara tiang kayu harus diberi ikatan diagonal.

c. Ketentuan Struktur Atas

1) Rangka kuda-kuda harus kuat menahan beban atap
2) Rangka kuda-kuda harus diangker pada kedudukannya (pada kolom atau ring balok).

3) Pada arah memanjang atap harus diperkuat dengan menambah ikatan angin diantara rangka kudakuda.

2. Menjamin Kesehatan

a. kecukupan pencahayaan rumah layak huni minimal $50 \%$ dari dinding yang berhadapan dengan ruang terbuka untuk ruang tamu dan minimal $10 \%$ dari dinding yang berhadapan dengan ruang terbuka untuk ruang tidur;

b. kecukupan penghawaan rumah layak huni minimal $10 \%$ dari luas lantai.

c. penyediaan sanitasi minimal 1 kamar mandi dan jamban didalam atau luar bangunan rumah dan dilengkapi bangunan bawah septiktank atau dengan sanitasi komunal.

3. Memenuhi Kecukupan luas minimum Luas minimal rumah layak huni antara 7,2 m2/orang sampai dengan 12 m2/orang dengan fungsi utama sebagai hunian yang terdiri dari ruang serbaguna/ruang tidur dan dilengkapi dengan kamar mandi.

Kriteria menurut UN Habitat memiliki cakupan yang lebih kompleks dimana sebuah permukiman perlu mempertimbangkan berbagai aspek seperti keamanan, ketersediaan layanan, bahan dan infrastruktur, keterjangkauan dalam aspek finansial keuangan, kelayakan huni, aksesibilitas, lokasi, serta kecukupan dalam aspek kebutuhan terhadap budaya masyarakat. Hal ini terlalu ringkas apabila hanya ditilik dari aspek teknis yang dicantumkan dalam peraturan pemerintah. Peraturan Menteri Negara Perumahan Rakyat Republik Indonesia No : 22 / PERMEN / M / 2008 sebenarnya saling beririsan dengan kriteria UN Habitat namun hanya mencangkup aspek kelayakan huni saja tidak mencangkup kompleksitas kebutuhan hunian masyarakat urban perkotaan dalam aspek ekonomi sosial dan budaya. 


\section{On-Site Upgrading untuk memenuhi Adequate Housing}

Terdapat lima alternatif pendekatan utama yang disusun oleh (UN-Habitat, 2008) untuk memecahkan masalah perumahan perkotaan, yang telah diterapkan dengan berbagai tingkat keberhasilan:

\section{On-Site Upgrading \\ 2. Resettlement \\ 3. Goverment-built new Public Housing \\ 4. Sites and Services \\ 5. City-Wide Housing Strategies}

Catatan-catatan seperti kondisi fisik bangunan dan lingkungan yang kurang baik, ketidakteraturan, kerapatan bangunan serta sarana-prasarana yang kurang (Sumintarsih \& Adrianto, 2014), karakteristik pedesaan (Funo et al., 2002), serta kondisi lingkungan multidimensi dengan entitas fisik, sosial dan ekonomi. yang heterogen dari penghuni, serta kompleksitas nilai-nilai tradisional (Hutama, 2016) menjadikan on-site upgrading dinilai paling relevan terhadap konteks permasalahan kampung kota.

On-site upgrading menurut (UN-Habitat, 2008) berarti meningkatkan lingkungan fisik, sosial dan ekonomi dari permukiman informal yang ada, tanpa menggusur orang-orang yang tinggal di sana. Ketika kota dan pemerintah mendukung proses upgrading komunitas informal, itu adalah cara paling murah dan paling manusiawi untuk meningkatkan persediaan perumahan terjangkau yang sangat dibutuhkan kota, daripada menghancurkannya.

Banyak orang berpikir tentang upgrading permukiman kumuh tetapi mereka cenderung hanya memikirkan programprogram teknis untuk memasang jalan beraspal, saluran air, saluran pasokan air, lampu jalan, jaringan listrik, sanitasi dan pembuangan sampah. Barang-barang infrastruktur ini pasti ada dalam daftar yang dibutuhkan. Sebetulnya terdapat versi upgrading yang lebih komprehensif dan menyeluruh. Versi upgrading yang lebih komprehensif dapat membantu warga komunitas untuk melakukan lebih banyak lagi.
Menurut (UN-Habitat, 2008) upgrading yang komprehensif perlu meliputi aspekaspek berikut ini :

1. Rumah: untuk memperbaiki rumah mereka atau membangun kembali seluruhnya.

2. Lahan: untuk mengatur dan mengamankan kepemilikan lahan jangka panjang mereka.

3. Pendapatan: untuk meningkatkan pendapatan dari pekerjaan mereka, menaikkan kapasitas dan membuka peluang usaha kecil.

4. Fasilitas umum: untuk meningkatkan fasilitas mereka seperti pusat komunitas, taman bermain atau tempat usaha masyarakat.

5. Akses ke layanan publik: untuk meningkatkan akses ke pendidikan dan perawatan kesehatan.mereka.

6. Kesejahteraan: untuk mengatur kesejahteraan yang dikelola

7. Sistem yang dapat menjaga anggota mereka yang paling rentan.

Upgrading biasanya melibatkan beberapa perubahan pada tata letak komunitas yang ada, untuk memberi ruang bagi pemasangan fasilitas infrastruktur. Tetapi perubahan ini tidak perlu besar, kecuali masyarakat memilih untuk membangun kembali pemukiman mereka sepenuhnya, dan memulai dari awal dengan rencana baru, infrastruktur dan perumahan. Komunitas dapat menentukan cara yang bijaksana untuk mengakomodasi kebutuhan orang-orang yang rumahnya harus dihancurkan atau dipindahkan untuk perbaikan. Ada banyak pilihan, dan sifat dari setiap proyek upgrading tergantung pada prioritas dan sumber daya dari orangorang yang tinggal di komunitas itu (UNHabitat, 2008).

\section{Kelebihan Strategi On-Site Upgrading}

Strategi Upgrading memiliki banyak kelebihan. Pada hakikatnya Upgrading menjaga orang-orang tetap berada dimana mereka telah hidup, hal ini membantu mengkonsolidasikan masyarakat, meningkatkan stabilitas sosial dan membangun mekanisme dukungan yang ada (UN-Habitat, 2008). 
Upgrading keeps people together in the same place where they already live, so it helps consolidate communities, enhance social stability and build on existing support mechanisms.(UN-Habitat, 2008)

Selain poin tersebut di atas (UN-Habitat, 2008) menjabarkan berbagai keuntungan yang lain dari On-Site Upgrading seperti hal-hal berikut ini :

1. Upgrading mendorong partisipasi dalam banyak aspek dari pembangunan kembali masyarakat dala hal perencanaan dan pelaksanaan proyek kemudian di banyak kegiatan sosialekonomi lainnya yang dikelola di dalam masyarakat.

2. Upgrading menstimulasi orang berinvestasi dalam perbaikan perumahan dan lingkungan hidup mereka dengan mengesahkan hak-hak jangka panjang mereka untuk menempati lahan melalui kepemilikan lahan jangka panjang yang aman.

3. Upgrading meningkatkan kondisi kesejahteraan dan kehidupan orangorang dengan memperbaiki perumahan dan lingkungan tempat tinggal mereka dan dengan membebaskan mereka dari ancaman pengusiran.

4. Upgrading membangun aset dan meningkatkan nilai rumah dan tanah orang, dengan meningkatkan keamanan kepemilikan lahan. Sebagai aset, rumah-rumah dapat digunakan untuk kegiatan yang menghasilkan pendapatan, disewa atau dijual dalam krisis, atau digunakan sebagai jaminan untuk mendapatkan pinjaman.

5. Upgrading meningkatkan tata letak pemukiman. Ketika orang-orang meningkatkan pemukiman yang padat dan tidak direncanakan, mereka dapat mengatur kembali plot dan menyediakan ruang untuk infrastruktur, pra-sekolah, taman bermain, klinik dan tempat ibadah.

6. Upgrading membangun semangat dan kebanggaan. Meningkatkan perumahan komunitas miskin dan layanan dasar tidak hanya memenuhi fungsi penting pemerintah lokal, tetapi juga meningkatkan moral, kebanggaan, keterlibatan sipil, dan ambisi orang untuk berinvestasi lebih lanjut di rumah dan lingkungan mereka.

7. Upgrading meningkatkan pendapatan ketika orang dapat menggunakan rumah mereka untuk mendapatkan penghasilan: toko, penyewaan kamar, dan lokakarya rumah. Memiliki alamat resmi juga memudahkan untuk mendapatkan pekerjaan dengan gaji lebih baik di sektor formal.

\section{Prinsip-Prinsip dalam On-Site Upgrading}

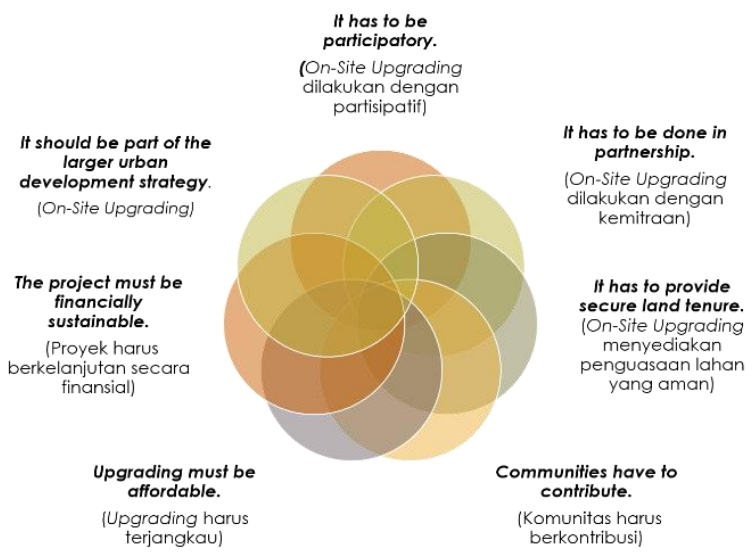

Gambar 1: Prinsip On-Site Upgrading menurut UN Habitat

(Sumber: UN Habitat, 2008,16)

Prinsip-prinsip On-Site Upgrading menurut (UN-Habitat, 2008) meliputi :

1. It has to be participatory. (On-Site Upgrading dilakukan dengan partisipatif) Upgrading harus menjadi proses partisipatif yang membahas kebutuhan masyarakat yang diidentifikasi secara kolektif oleh para anggotanya. Hal ini adalah kunci keperhasilan proyek. Tanpa partisipasi ini perbaikan infrastruktur tidak akan bisa dipertahankan, kondisi akan memburuk, orang akan menjadi kecewa dengan pemerintah lokal mereka dan investasi dalam peningkatan akan sia-sia. Semakin banyak komunitas berpartisipasi dalam setiap tahap proses, semakin sukses hasilnya.

2. It has to be done in partnership. (On-Site Upgrading dilakukan dengan kemitraan) 
Merencanakan dan melaksanakan proyek upgrading selalu lebih efektif bila dilakukan oleh komunitas dan pemerintah setempat, dalam kerja sama erat. LSM juga dapat memainkan peran penting dalam mendukung organisasi masyarakat, serta memberi mereka dukungan teknis yang mereka perlukan dalam merancang perbaikan perumahan atau mengembangkan proyek-proyek penghasil pendapatan.

3. It has to provide secure land tenure. (On-Site Upgrading menyediakan penguasaan lahan yang aman)

Memberikan jaminan kepemilikan adalah bagian penting dari upgrading. Tanpa itu, keberlanjutan orang-orang terhadap penggusuran akan membuat mereka enggan berinvestasi lebih jauh di perumahan dan lingkungan hidup mereka. Terkadang kepemilikan diberikan kepada rumah tangga individu dalam bentuk akta kepemilikan atau kontrak sewa, setelah batas-batas telah diukur dan dicatat. Memberikan hak penguasaan kepada kepala rumah tangga perempuan dapat melindungi anak-anak dari ancaman pengabaian dan tunawisma dan memberi mereka aset yang dapat mereka gunakan untuk menghasilkan pendapatan. Kepemilikan lahan semakin sering diberikan secara kolektif, kepada masyarakat secara keseluruhan, sebagai sarana untuk mencegah gentrifikasi dan membangun organisasi komunitas yang lebih kuat.

4. Communities have to contribute. (Komunitas harus berkontribusi)

Merupakan hal yang penting bagi komunitas untuk berkontribusi pada Upgrading dalam beberapa cara. Pengalaman menunjukkan kontribusi komunitar memperkuat rasa kepemilikan komunitas atas proses upgrading. Kontribusinya dapat berupa uang (pinjaman tunai atau pinjaman masyarakat) atau dapat berupa sumbangan tenaga kerja atau bahan bangunan, atau beberapa campuran dari ini. Upgrading berfungsi paling baik ketika kontribusi komunitas dilengkapi dengan semacam subsidi, dari hibah donor atau dana proyek publik.

5. Upgrading must be affordable. (Upgrading harus terjangkau)
Jumlah bantuan finansial yang dapat diberikan pada sebuah rumah tangga akan membantu menentukan ruang lingkup dan isi paket upgrading. Jika program upgrading. datang dengan pajak tinggi atau biaya pengguna yang tidak terjangkau oleh masyarakat, mereka mungkin tidak akan menggunakan atau memelihara fasilitas, atau mungkin pindah ke pemukiman yang lebih terjangkau di tempat lain.

6. The project must be financially sustainable.

(Proyek harus berkelanjutan secara finansial)

Keberlanjutan sebagian berasal dari cara pembiayaan upgrading. Paling baik bila dana dari beberapa sumber digabungkan, termasuk sumbangan anggota masyarakat, subsidi dan pinjaman dari pemerintah, dan mungkin dukungan dari organisasi pembangunan internasional atau lokal.

7. It should be part of the larger urban development strategy.

(On-Site Upgrading harus manjadi bagian dari strategi pengembangan urban yang lebih besar)

Proyek peningkatan komunitas harus dilihat sebagai bagian penting dari visi kota yang lebih besar mengenai perkembangan masa depannya. Proyek tidak boleh menjadi inisiatif darurat yang dilaksanakan secara terpisah, tetapi harus menjadi bagian dari rencana untuk pengelolaan perkotaan secara keseluruhan yang berupaya mengatasi masalah perumahan di skala kota.

\section{Tahapan pelaksanaan On-Site Upgrading}

Pelaksanaan On-Site Upgrading terbagi ke dalam tujuh tahapan menurut (UN-Habitat, 2008) berikut ini :

1. Selecting the settlement that is to be upgraded

(Memilih Permukiman sebagai Obyek On-Site Upgrading.)

Menentukan lokasi permukiman melibatkan berbagai pertimbangan berdasarkan prioritas. Hal ini pada umumnya dilakukan oleh perencana 
dari pemerintah yang bertugas mengidentifikasi permukiman yang sesuai. Tidak menutup kemungkinan inisiatif dapat dilakukan oleh komunitas miskin lokal, LSM maupun pemangku kepentingan lainnya. Hal-hal yang dapat mereka pertimbangkan dalam memilih permukiman diantaranya adalah :

a. Kesiapan masyarakat untuk berpartisipasi

b. Kondisi fisik sebuah permukiman

c. Biaya

d. Masalah kepemilikan lahan

e. Konteks pembangunan kota secara lebih besar.

2. Strenghtening the Community's internal Organization.

(Memperkuat Organisasi Internal Komunitas)

Penguatan organisasi internal komunitas adalah langkah penting dalam proses on-site upgrading. Sebagai aktor utama dalam upgrading, sebuah komunitas harus mampu memastikan setiap proses dapat memenuhi kebutuhan semua anggota komunitas dan tidak hanya sebagian kecil saja. Komunitas harus mampu bernegosiasi dengan pemerintah lokal, mengidentifikasi dan menyampaikan kebutuhan dan berpartisipasi dalam semua proses perencanaan, implementasi dan pemeliharaan.

3. Organizing meeting to get stakeholders involved.

(Mengorganisir pertemuan untuk melibatkan para pemangku kebijakan)

Serangkaian pertemuan dengan pemangku kepentingan akan menjadi alat yang paling berguna dalam membantu melaksanakan program upgrading, memastikan setiap orang tahu apa yang dilakukan oleh program, dan menyiapkan mekanisme yang akan digunakan selama tahap perencanaan dan pelaksanaan proyek.

Menjadi catatan penting bahwa pertemuan ini perlu memiliki agenda terbuka dan kerangka waktu yang terbuka sehingga orang akan merasa bebas untuk mengutarakan pikiran mereka serta mengungkapkan ide mereka dalam forum.
4. Surveying all aspects of the community (Melakukan survei pada semua aspek komunitas)

Step selanjutnya adalah untuk melakukan survei yang mendetail, pemetaan komunitas dan menyusun peta permukiman yang baik, yang menunjukkan semua rumah, titik air, fasilitas dan bidang masalah. Ini adalah cara untuk memperoleh informasi fisik dan sosial-ekonomi yang akurat. Informasi ini akan memainkan bagian penting dalam pengembangan rencana upgrading. Ketika masyarakat mempersiapkan rencana mereka sendiri dalam melakukan upgrading permukiman menjadi memungkinkan proses upgrading untuk dapat mencakup lebih dari sekedar aspek fisik dari komunitas mereka seperti perumahan dan infrastruktur. Upgrading juga dapat mencakup pengembangan sosial dan ekonomi, peningkatan yang lebih menyeluruh dan dapat mengarah pada kehidupan yang lebih baik lagi bagi banyak orang dan dalam banyak hal.

5. Designing all aspects of the upgrading plan

(Merancang semua aspek rencana OnSite Upgrading)

Langkah ini termasuk menyiapkan rencana fisik final untuk tata letak dan infrastruktur masyarakat, merancang rumah dan fasilitas masyarakat, menetapkan jadwal konstruksi dan sistem kontrak kerja, dan mebangun siste di dalam masyarakat untuk mempertahankan perbaikan ini setelah proyek berakhir. Tahap ini juga termasuk persiapan rencana keuangan, perkiraan biaya terperinci dan rencana untuk membiayai keseluruhan proyek:

a. Berapa biaya keseluruhan

b. Siapa yang akan membayar dan untuk apa

c. Bagaimana dana akan mengalir

d. Siapa yang akan membeli materi

e. Bagaimana uang akan dikelola

6. Carrying out the actual upgrading work (Melaksanakan pekerjaan upgrading)

Pada tahap ini pekerjaan betul-betul dilakukan dan sebuah permukiman kumuh diubah menjadi lingkungan baru yang bersih dan terawat dengan baik. 
Selama tahap ini rumah dibangun atau diperbaiki, saluran air dipasang, jaringan pipa air dikubur dan dihubungkan ke rumah-rumah individu, jalur-jalur diaspal, tiang listrik dipasang, pohon ditanam dan pagar dilukis. Semua pekerjaan ini dapat dilakukan dengan cara yang berbeda. Pada kondisi ekstrim, semua pekerjaan dapat dilakukan oleh kontraktor melalui tender, dapat pula dilaksanakan oleh pembangun dan LSM. Pada kondisi ekstri yang lain seluruh proyek dapat dibangun oleh anggota komunitas itu sendiri yang menyumbangkan tenaga mereka dan mengelola semuanya secara kolektif.

7. Continue meetings as a platform for further work.

(Melanjutkan pertemuan sebagai platform untuk pekerjaan lebih lanjut)

Proses komunitas tidak berhenti ketika pekerjaan fisik selesai. Pemeliharaan jangka panjang juga merupakan tugas penting bagi masyarakat. Proyek upgrading yang baik dapat meningkatkan percaya diri komunitas dan mengilhami mereka untuk terus melaksanakan pengembangan lebih lanjut. Proyek upgrading tidak hanya berupa perbaikan fisik tetapi juga perubahan sosial-ekonomi seperti usaha masyarakat, skema kesejahteraan yang dikelola masyarakat, fasilitas olahraga, sistem kesehatan, kegiatan pemuda, dan kelompok lansia.

\section{Penutup}

\section{Kesimpulan}

Uraian di atas menunjukkan kebutuhan untuk mempertimbangkan berbagai aspek dalam penyelesaian permasalahan perumahan dan permukiman dengan strategi on-site upgrading. Pelaksanaan on-site upgrading perlu mempertimbangkan berbagai dimensi sosial, ekonomi, kelembagaan serta kondisi fisik dan spasial tempat dilaksanakannya upgrading. Dengan perhatian menyeluruh terhadap berbagai aspek tersebut tentunya dapat dikembangkan on-site upgrading secara tepat di Indonesia.

\section{Ucapan Terimakasih}

Kami. Tim Penulis, mengucapkan terima kasih dan berharap kajian-kajian di dalam jurnal ini dapat memberikan wawasan bagi para pembaca. Ucapan terima kasih, kami berikan secara khusus, kepada:

1. Rektor Universitas Katolik Soegijapranata Semarang.

2. Dekan Fakultas Arsitektur dan Desain Universitas Katolik Soegijapranta Semarang.

3. Wakil Dekan I Fakultas Arsitektur dan Desain Universitas Katolik Soegijapranta Semarang.

4. Ketua Jurusan Program Studi Arsitektur Universitas Katolik Soegijapranta Semarang.

5. Ketua Redaksi.

6. Tim Penyuting.

7. Tim Mitra Bestari.

\section{Daftar Pustaka}

Funo, S., Yamamoto, N., \& Silas, J. (2002). Typology of Kampung Houses and Their Transformation Process. Journal of Asian Architecture and Building Engineering, 1(2), 193-200. https://doi.org/10.3130/jaabe.1.2_193

Hutama, I. A. W. (2016). Exploring the Sense of Place of an Urban Through the Daily Activities, Configuration of Space and Dweller's Perception: Case Study of Kampung Code, Yogyakarta. University of Twente. Diambil dari www.itc.nl/library/papers_2016/msc/u pm/hutama.pdf

Nagle, G. (1998). Changing Settlements (1 ed.). London: Thomas Nelson \& Sons Ltd.

Nugroho, A. C. (2010). Spatial Enclosure sebagai Dasar Penataan Kampung Kota. Jurnal Arsitektur Universitas Bandar Lampung, 1(1), 26-28.

Tesa Arsitektur Volume 18| Nomor 2 | 2020 
Peraturan Menteri Negara Perumahan Rakyat Republik Indonesia No: 22 I PERMEN / M / 2008 tentang Standar Pelayanan Minimal Bidang Perumahan Rakyat Daerah Provinsi dan Daerah Kabupaten/Kota. (2008) (hal. 33). Jakarta: Kementerian Perumahan Rakyat.

Raharjo, W. (2010). Speculative Settlements: Built Form/Tenure Ambiguity in Kampung Development. University of Melbourne.

Simarmata, H. A. (2018). Phenomenology in Adaptation Planning: An Empirical Study of Flood-affecterd in Kampung Muara Baru Jakarta. Singapore: Springer Nature Singapore Pte Ltd.

Singh, S. B. (1995). Emerging Frontiers of Urban Settlement Geography. New Delhi: M D Publications Pvt Ltd.

Sumintarsih, \& Adrianto, A. (2014). Dinamika Kampung Kota Prawirotaman dalam Perspektif Sejarah dan Budaya. Balai Pelestarian Nilai Budaya (BPNB) Daerah Istimewa Yogyakarta. Diambil dari http://www.bpnb-jogja.info

UN-Habitat. (2008). Housing The Poor in Asian Cities - Low-Income Housing: Approaches to Help the Urban Poor Find Adequate Accomodation. Bangkok: UNESCAP \& UN-HABITAT.

UN-Habitat. (2015). Habitat III Issue Paper: Housing. Habitat III, 2015(May), 0-8. https://doi.org/http://dx.doi.org/10.340 2/gha.v5i0.19065

UNHC-HR. (2009). The Right to Adequate Housing (Vol. 21). Geneva: Office of United Nations High Commisioner for Human Rights. 